\title{
Profile of blonanserin for the treatment of schizophrenia
}

This article was published in the following Dove Press journal:

Neuropsychiatric Disease and Treatment

26 April 2013

Number of times this article has been viewed

\section{Tomomi Tenjin \\ Seiya Miyamoto \\ Yuriko Ninomiya \\ Rei Kitajima \\ Shin Ogino \\ Nobumi Miyake \\ Noboru Yamaguchi}

Department of Neuropsychiatry, St Marianna University School of Medicine, Kawasaki, Kanagawa, Japan
Correspondence: Tomomi Tenjin Department of Neuropsychiatry, St Marianna University School of Medicine, 2-16-I Sugao, Miyamae-ku, Kawasaki, Kanagawa 2I6-85II, Japan Tel +8I 449778 I I I

Fax +8I 44976334

Email t2tenjin@marianna-u.ac.jp
Abstract: Blonanserin was developed as an antipsychotic drug in Japan and approved for the treatment of schizophrenia. It belongs to a series of 4-phenyl-2-(1-piperazinyl)pyridines and acts as an antagonist at dopamine $\mathrm{D}_{2}, \mathrm{D}_{3}$, and serotonin $5-\mathrm{HT}_{2 \mathrm{~A}}$ receptors. Blonanserin has low affinity for $5-\mathrm{HT}_{2 \mathrm{C}}$, adrenergic $\alpha_{1}$, histamine $\mathrm{H}_{1}$, and muscarinic $\mathrm{M}_{1}$ receptors, but displays relatively high affinity for 5 - $\mathrm{HT}_{6}$ receptors. In several short-term double-blind clinical trials, blonanserin had equal efficacy as haloperidol and risperidone for positive symptoms in patients with chronic schizophrenia and was also superior to haloperidol for improving negative symptoms. Blonanserin is generally well tolerated and has a low propensity to cause metabolic side effects and prolactin elevation. We recently reported that blonanserin can improve some types of cognitive function associated with prefrontal cortical function in patients with firstepisode and chronic schizophrenia. Taken together, these results suggest that blonanserin may be a promising candidate for a first-line antipsychotic for acute and maintenance therapy for schizophrenia. Further comparative studies are warranted to clarify the benefit/risk profile of blonanserin and its role in the treatment of schizophrenia.

Keywords: blonanserin, schizophrenia, pharmacology, pharmacokinetics, efficacy, safety

\section{Introduction}

Schizophrenia is a heterogeneous devastating psychiatric disorder characterized by positive, negative, affective, and cognitive symptoms. It generally presents in late adolescence or early adulthood and is associated with an increased risk of mortality and social or occupational dysfunction. ${ }^{1}$ Most patients with the illness usually need life-long treatment, and antipsychotic drugs are the mainstay of the pharmacologic treatment for schizophrenia. ${ }^{2}$

The introduction of second-generation antipsychotics (SGAs) or atypical antipsychotics represented an important advance in the pharmacologic treatment of the disorder. ${ }^{3,4}$ Accumulating evidence suggests that SGAs have at least equal or superior efficacy as first-generation antipsychotics (FGAs) and may offer some advantages over FGAs such as fewer extrapyramidal symptoms (EPS). ${ }^{5-8}$ SGAs excluding clozapine are currently recommended in many guidelines as first-line agents for acute and maintenance therapy for schizophrenia. ${ }^{9-11}$ However, increased concern has arisen regarding the safety profile of SGAs, as problems such as weight gain, metabolic abnormalities, and/or hyperprolactinemia have been noted. ${ }^{3,4}$ These side effects are associated with potential long-term health risks for patients as well as decreased adherence to treatment regimens. The need for more effective and safer agents has prompted the development of new antipsychotics. ${ }^{12}$ 
Blonanserin was developed as a novel antipsychotic drug in Japan and was approved in Japan in 2008 and Korea in 2009 for the treatment of schizophrenia. It is currently under clinical investigation in a Phase III trial in the People's Republic of China. ${ }^{13}$ This article reviews the available data about the pharmacological profile, clinical efficacy, safety, and tolerability of blonanserin, and discusses its place in the treatment of schizophrenia as well as future perspectives.

\section{Pharmacological profile Pharmacodynamics}

Blonanserin belongs to a series of 4-phenyl-2-(1-piperazinyl) pyridines and acts as an antagonist at dopamine $\mathrm{D}_{2}, \mathrm{D}_{3}$, and serotonin $5-\mathrm{HT}_{2 \mathrm{~A}}$ receptors (Table 1 ). ${ }^{14}$ Its affinity for $\mathrm{D}_{2}$ receptors is approximately 6 times greater than that for $5-\mathrm{HT}_{2 \mathrm{~A}}$ receptors. This feature is different from that of most other SGAs. Thus, blonanserin is pharmacologically more similar to FGAs than new generation drugs, ${ }^{4}$ and in Japan, it is often called a "dopamine-serotonin antagonist". ${ }^{15}$ The affinity of blonanserin for $\mathrm{D}_{2}$ receptors is 20 - and 94-fold higher than that of haloperidol and risperidone, respectively.

In contrast, blonanserin has low affinity for $5-\mathrm{HT}_{2 \mathrm{C}}$, adrenergic $\alpha_{1}$, histamine $H_{1}$, and muscarinic $M_{1}$ receptors (Table 1). ${ }^{14}$ These receptor binding profiles may minimize its potential to induce certain adverse effects such as orthostatic hypotension, oversedation, weight gain, metabolic abnormalities, and peripheral anticholinergic side effects. ${ }^{16,17}$
Blonanserin has a relatively high affinity for $5-\mathrm{HT}_{6}$ receptors $\left(\mathrm{K}_{\mathrm{i}}=11.7 \mathrm{nM}\right)$ that is likely involved in the improvement of cognitive function. ${ }^{18}$ It also shows low inhibitory activity of neuronal re-uptake of dopamine, 5-HT, and norepinephrine. ${ }^{17}$ A positron emission tomography (PET) study of healthy volunteers showed that blonanserin occupies approximately $80 \%$ of striatal $\mathrm{D}_{2}$-like receptors with normal clinical doses. ${ }^{16}$

A preclinical study demonstrated that systematic administration of blonanserin increases extracellular levels of norepinephrine and dopamine, but not levels of 5-HT, glutamate, or gamma-aminobutyric acid in the prefrontal cortex. ${ }^{19}$ It also enhances neuronal activity in the locus coeruleus and ventral tegmental area without affecting activity in the dorsal raphe nucleus or the mediodorsal thalamic nucleus. Another study showed that blonanserin attenuates the enhancement of immobility in the forced swimming test induced by repeated treatment with phencyclidine in mice. ${ }^{14}$ Moreover, it improves apomorphine-induced prepulse inhibition disruption in rats. These effects of blonanserin suggest a potential efficacy for treating negative symptoms and cognitive impairment in schizophrenia.

\section{Pharmacokinetics}

Blonanserin is rapidly absorbed from the gastrointestinal tract (with the exception of the stomach) after oral administration and reaches a maximum plasma concentration $\left(\mathrm{C}_{\max }\right)$ within 2 hours in healthy volunteers. ${ }^{20}$ Steady-state levels

Table I Receptor binding affinities of blonanserin, risperidone, and haloperidol $\left(\mathrm{K}_{\mathrm{i}}\right.$ values, $\left.\mathrm{nM}\right)$

\begin{tabular}{|c|c|c|c|c|c|}
\hline Receptor & Preparation & Ligand & Blonanserin & Risperidone & Haloperidol \\
\hline \multicolumn{6}{|l|}{ Dopamine } \\
\hline$D_{1}$ & Human recombinant & ${ }^{3} \mathrm{H}-\mathrm{SCH} 23390$ & I,070 & 761 & 2,300 \\
\hline $\mathrm{D}_{2}$ & Human recombinant & ${ }^{3} \mathrm{H}$-spiperone & 0.142 & 13.2 & 2.73 \\
\hline $\mathrm{D}_{3}$ & Human recombinant & ${ }^{3} \mathrm{H}$-spiperone & 0.494 & & \\
\hline $\mathrm{D}_{4}$ & Human recombinant & ${ }^{3} \mathrm{H}$-spiperone & 150 & & \\
\hline$D_{5}$ & Human recombinant & ${ }^{3} \mathrm{H}-\mathrm{SCH} 23390$ & 2,600 & & \\
\hline \multicolumn{6}{|l|}{ Serotonin } \\
\hline $5-\mathrm{HT}_{\text {IA }}$ & Human recombinant & ${ }^{3} \mathrm{H}-8-\mathrm{OH}-\mathrm{DPAT}$ & 804 & & \\
\hline $5-\mathrm{HT}_{2 \mathrm{~A}}$ & Human recombinant & ${ }^{3} \mathrm{H}$-ketanserin & 0.812 & 1.09 & 45.7 \\
\hline $5-\mathrm{HT}_{2 \mathrm{C}}$ & Human recombinant & ${ }^{3} \mathrm{H}$-mesulergine & 26.4 & & \\
\hline $5-\mathrm{HT}_{6}$ & Human recombinant & ${ }^{125}$ I-LSD & 41.9 & & \\
\hline $5-\mathrm{HT}_{7}$ & Human recombinant & ${ }^{125}$ I-LSD & 183 & & \\
\hline \multicolumn{6}{|l|}{ Adrenergic } \\
\hline$\alpha_{1}$ & Rat brain & ${ }^{3} \mathrm{H}$-prazosin & 26.7 & 0.657 & 8.75 \\
\hline$\alpha_{2}$ & Rat cortex & ${ }^{3} \mathrm{H}-\mathrm{R} \times 82 \mathrm{I} 002$ & 530 & & \\
\hline \multicolumn{6}{|l|}{ Histamine } \\
\hline $\mathrm{H}_{1}$ & Human recombinant & ${ }^{3} \mathrm{H}$-pyrilamine & 765 & & \\
\hline \multicolumn{6}{|l|}{ Muscarinic } \\
\hline$M_{1}$ & Human recombinant & ${ }^{3} \mathrm{H}-\mathrm{NMS}$ & 100 & & \\
\hline
\end{tabular}

Note: Data are mean values. Data reprinted from Jpn J Clin Psychopharmacol, Volume 10, Une T, Kurumiya S, Pharmacological profile of blonanserin, pages I263-1272. Copyright @ 2007, with permission from Seiwa Shoten Publishers Tokyo.

Abbreviations: LSD, lysergic acid diethylamide; NMS, N-methyl scopolamine. 
of blonanserin are attained within 5 days after repeated administration of blonanserin ( $4 \mathrm{mg} /$ day) in healthy individuals, ${ }^{20}$ and the plasma concentration is correlated with the administered dose. ${ }^{21}$ Binding to plasma proteins is almost $100 \%$ over the concentration range of $10 \mathrm{ng} / \mathrm{mL}-2 \mu \mathrm{g} / \mathrm{mL}$ with albumin contributing the most to binding. ${ }^{20}$ Brain uptake is extensive, and P-glycoprotein, an efflux transporter expressed in the brain, does not actively transport blonanserin as a substrate in humans or mice. ${ }^{22}$ Results of PET studies, in which $\mathrm{D}_{2}$ receptor occupancy of several antipsychotics in the pituitary and temporal cortex was calculated, demonstrated that blonanserin has the highest brain/plasma concentration ratio $(\mathrm{B} / \mathrm{P}$ ratio $=3.88)$ compared with that of olanzapine $(\mathrm{B} / \mathrm{P}$ ratio $=2.70)$, haloperidol $(\mathrm{B} / \mathrm{P}$ ratio $=2.40)$, risperidone $(\mathrm{B} / \mathrm{P}$ ratio $=1.61)$, and sulpiride $(\mathrm{B} / \mathrm{P}$ ratio $=0.34){ }^{23,24}$ The $\mathrm{B} / \mathrm{P}$ ratio represents the penetrating capability of antipsychotics across the blood-brain barrier, ${ }^{23}$ and thus, blonanserin appears to pass into the brain more easily than these other antipsychotics.

Food significantly affects the bioavailability of blonanserin in healthy individuals. Both $\mathrm{C}_{\max }$ and area under the plasma concentration-time curve (AUC) from time 0 to 12 hours after a single oral administration of blonanserin are 2.7-fold higher in the fed state compared with the fasting state, and the time to $\mathrm{C}_{\max }\left(\mathrm{T}_{\max }\right)$ is significantly prolonged under fed conditions. ${ }^{20}$ Thus, blonanserin should be taken after meal intake. However, Saruwatari et $\mathrm{al}^{25}$ demonstrated that the increase in systemic exposure to blonanserin continues until at least 4 hours after food intake, and thus, the drug can be administered immediately before bedtime.

Blonanserin is mainly metabolized by cytochrome P450 (CYP) 3A4 in the liver, and its major metabolites are M-1 (N-deethylated blonanserin) and M-3 (7- and 8-hydroxylated blonanserin). ${ }^{20} \mathrm{M}-1$ has the highest binding affinity for $\mathrm{D}_{2 / 3}$ receptors and $5-\mathrm{HT}_{2 \mathrm{~A}}$ receptors, but it shows pharmacological activity several fold lower than that of the parent drug. ${ }^{16}$

Elimination of blonanserin is predominantly in the urine and feces. ${ }^{20}$ The terminal elimination half-life $\left(t_{1 / 2}\right)$ of blonanserin was 10.7, 12.0, and 16.2 hours after administration of a single oral dose of 4,8 , and $12 \mathrm{mg}$, respectively, in healthy volunteers. Thus, the manufacturer's prescribing information recommends twice-daily administration. However, the elimination $t_{1 / 2}$ was 67.9 hours after repeated administration of blonanserin ( $4 \mathrm{mg}$ /day) for 10 days in healthy individuals. ${ }^{20}$ Thus, it can be effectively administered once a day in clinical practice.

\section{Drug interactions}

As described previously, blonanserin is predominantly metabolized by CYP3A4. Coadministration of potent CYP3A4 inhibitors such as azole antifungal agents and human immunodeficiency virus protease inhibitors with blonanserin may increase the plasma concentration of blonanserin, and coadministration of these drugs is contraindicated. ${ }^{20}$ In addition, concomitant administration of blonanserin with adrenaline is contraindicated due to the potential risks of serious reductions in blood pressure.

The package inserts also provide cautions about coadministration of blonanserin with other CYP3A4 inhibitors such as erythromycin, clarithromycin, cyclosporine, diltiazem, and grapefruit juice. ${ }^{20}$ In contrast, CYP3A4 inducers such as phenytoin, carbamazepine, barbiturate, and rifampicin should be carefully administrated with blonanserin, because of the potential for decreased plasma blonanserin concentrations.

The effects of blonanserin may be enhanced after coadministration with central nervous system depressant drugs or alcohol and may be reduced after coadministration with dopamine agonists (eg, levodopa and bromocriptine), and patients should be cautioned to coadminister carefully. ${ }^{20}$

\section{Therapeutic efficacy}

The therapeutic efficacy of blonanserin for the treatment of patients with schizophrenia was evaluated in four comparative short-term trials ${ }^{26-29}$ and three non-comparative longterm studies. ${ }^{30-32}$

\section{Short-term efficacy}

Four randomized, double-blind, placebo- and active comparator-controlled clinical trials evaluated the short-term efficacy of blonanserin (Table 2). ${ }^{26-29}$ In a haloperidolcontrolled, 8-week Phase III trial, ${ }^{27}$ a total of 265 patients were randomized. Patients were randomly assigned to receive twice daily doses of blonanserin (8-24 $\mathrm{mg} /$ day) or haloperidol (4-12 mg/day). Results for the primary endpoint, the final global improvement rate (percentage of patients graded "markedly improved" or "moderately improved"), were $61.2 \%$ improvement in the blonanserin group and 51.3\% improvement in the haloperidol group. Blonanserin was non-inferior to haloperidol $(P=0.001)$. Secondary efficacy measures included scores from the Positive and Negative Syndrome Scale (PANSS) and the Brief Psychiatric Rating Scale (BPRS). No significant differences were found between the treatment groups regarding mean improvements from 


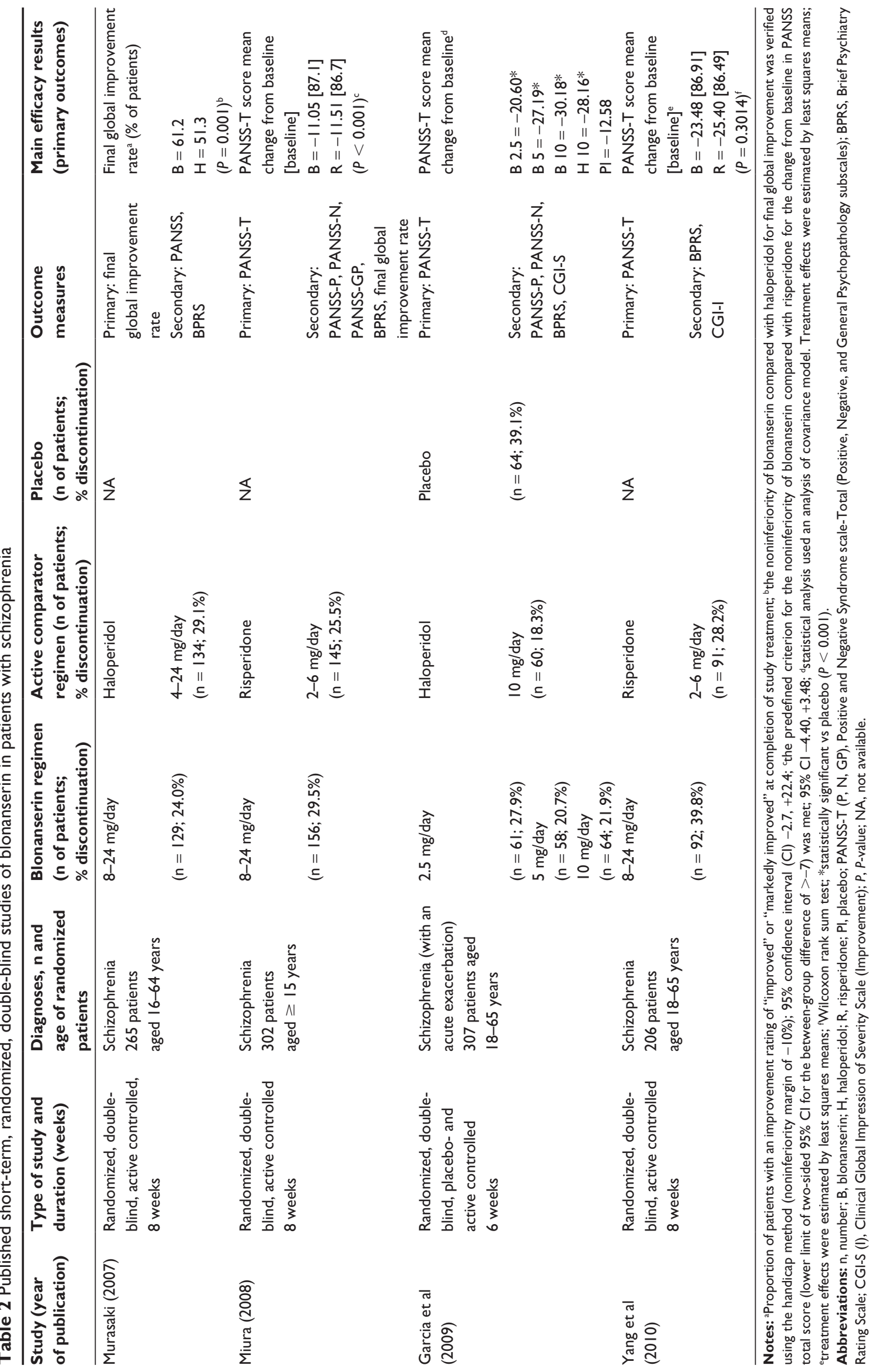


baseline in PANSS, BPRS total scores, PANSS positive or general psychopathological subscores. However, blonanserin produced significantly greater decreases in the PANSS negative subscale scores $(P=0.025)$ and the "anergia cluster" score of BPRS $(P=0.022)$ compared with haloperidol.

Garcia et $\mathrm{al}^{26}$ conducted a 6-week, placebo- and haloperidol-controlled, international, multicenter study in 307 patients with an acute exacerbation of schizophrenia. Patients were randomized into one of five treatment groups (blonanserin 2.5, 5, or $10 \mathrm{mg}$, haloperidol $10 \mathrm{mg}$, or placebo once daily). All active treatments produced significantly greater reductions from baseline in the PANSS total and positive scores at week 6 compared with placebo $(P<0.001)$. Blonanserin ( 5 and $10 \mathrm{mg} /$ day) was superior to haloperidol for treating the negative symptoms of schizophrenia.

In an 8-week, risperidone-controlled, Phase III trial conducted in Japan, ${ }^{28} 302$ patients with chronic schizophrenia were randomly assigned to receive twice daily doses of blonanserin (8-24 mg/day) or risperidone (2-6 mg/day). Blonanserin was as effective as risperidone regarding mean improvements from baseline in the PANSS total score and each of the subscale scores as well as the BPRS total and cluster scores.

Yang et $\mathrm{al}^{29}$ conducted an 8-week, risperidone-controlled trial in 206 Korean patients with chronic schizophrenia. Patients were randomly assigned to take twice daily doses of blonanserin (8-24 mg/day) or risperidone (2-6 mg/day). Blonanserin showed equal efficacy as risperidone regarding mean improvements from baseline in the PANSS total score and the subscale scores as well as the BPRS total and cluster scores.

Kishi et $\mathrm{al}^{13}$ recently performed a systematic review and meta-analysis of these four studies and found no significant differences in discontinuation due to any cause $(P=0.29)$ or due to ineffectiveness $(P=0.32)$ between blonanserin and other pooled antipsychotics. Moreover, they did not find significant heterogeneity in the response rate between blonanserin and other antipsychotics.

In summary, blonanserin had equal short-term efficacy as haloperidol and risperidone regarding positive symptoms in patients with chronic schizophrenia. It was also superior to haloperidol for improving negative symptoms.

\section{Long-term efficacy}

Three open-label, non-comparative studies were conducted in Japan to evaluate the long-term efficacy of blonanserin..$^{30-32}$

Data are available from two studies $\left(n=61^{30}\right.$ and $\left.321^{31}\right)$ that were both conducted for 28 and 52-56 weeks of treatment.
Of the 61 patients eligible for analysis, 48 patients $(78.7 \%)$ received blonanserin for 28 weeks, and 38 patients $(62.3 \%)$ were treated for up to 56 weeks. ${ }^{30}$ Of the 321 patients eligible for analysis, 264 patients $(82.2 \%)$ received blonanserin for 28 weeks, and 155 patients (48.3\%) were treated for more than 52 weeks. ${ }^{31}$ The final global improvement rate was $52 \%-87 \%$ after 28 or $52-56$ weeks of treatment. ${ }^{30,31}$ Blonanserin produced significant improvements from baseline in the PANSS total score and the subscale scores as well as the BPRS total score $(P<0.0001)$.

In an extended long-term trial, nine $(42.9 \%)$ of 21 patients who were enrolled in the study completed over 6 years of treatment with blonanserin. ${ }^{32}$ The final mean dose was $14.2 \mathrm{mg} /$ day, and the final global improvement rate was $86 \%$. Blonanserin produced significant reductions from baseline in the BPRS total score $(P<0.001)$.

In summary, these data suggest that blonanserin may have long-term efficacy for the treatment of schizophrenia. However, data on direct head-to-head comparison with other antipsychotics are lacking for the maintenance treatment of the illness.

\section{Effect of blonanserin on cognitive function}

Cognitive impairment is a core feature of schizophrenia ${ }^{33,34}$ and is present early in the course of the illness. ${ }^{35,36}$ A number of studies have reported a 1-2 standard deviation decline in performance on tests of multiple cognitive domains, including attention, executive function, memory, and processing speed, compared to healthy individuals. ${ }^{35,37-39}$ These cognitive deficits largely determine social and occupational functioning, as well as quality of life (QOL) in patients with schizophrenia. ${ }^{40}$

We previously conducted an 8-week, randomized, doubleblind comparison of blonanserin $(n=10)$ and risperidone $(n=12)$ to evaluate the effects of these antipsychotics on cognitive functions in patients with chronic schizophrenia. ${ }^{41}$ Both antipsychotics significantly improved some types of verbal memory, whereas greater improvement was seen with blonanserin for attention and processing speed.

We recently conducted an 8-week, open-label study to evaluate the effects of blonanserin on clinical efficacy including cognitive function and subjective QOL in patients with antipsychotic-naïve first-episode schizophrenia. ${ }^{42}$ Cognitive function was assessed with the Brief Assessment of Cognition in Schizophrenia Japanese-language version (BACS-J), ${ }^{43}$ and subjective QOL was assessed with the Schizophrenia Quality of Life Scale Japanese-language version (SQLS-J). ${ }^{44}$ 
Twenty-four patients were recruited and tested at baseline. Of these, 20 completed the study. The mean daily doses of blonanserin at the start after baseline assessment and at 8 weeks were $2.9 \mathrm{mg} /$ day and $7.2 \mathrm{mg} /$ day, respectively. Results of paired $t$-tests demonstrated that z-scores of the letter fluency score (verbal fluency) and the Tower of London score (executive function) assessed with BACS-J were significantly increased after treatment with blonanserin $(P<0.05$ each) (Figure 1). The effect sizes for these changes were in the moderate range $(0.58$ and 0.62 , respectively). All items on the PANSS, SQLS-J, and Clinical Global Impression-Severity of Illness Scale significantly improved after 8 weeks of treatment (all $P<0.01) .{ }^{42}$ These results suggest that blonanserin improves some types of cognitive function (letter fluency and executive function) that are associated with prefrontal cortical function in patients with first-episode schizophrenia. Moreover, blonanserin may have beneficial effects on psychiatric symptoms and subjective QOL in this population. Further studies with a large sample size and longer duration of treatment are warranted to confirm our findings.

\section{Safety and tolerability Short-term treatment}

In a meta-analysis of four short-term double-blind trials in 1080 patients with schizophrenia, blonanserin had a 0.31 lower risk of hyperprolactinemia than risperidone and haloperidol $(P<0.00001$, numbers-needed-to-harm $(\mathrm{NNH})=$ not significant). ${ }^{13}$ Blonanserin had lower rates of dizziness (risk ratio $(\mathrm{RR})=0.47, P=0.03, \mathrm{NNH}=$ not significant) and akathisia $(\mathrm{RR}=0.54, P=0.02, \mathrm{NNH}=7)$ than haloperidol.

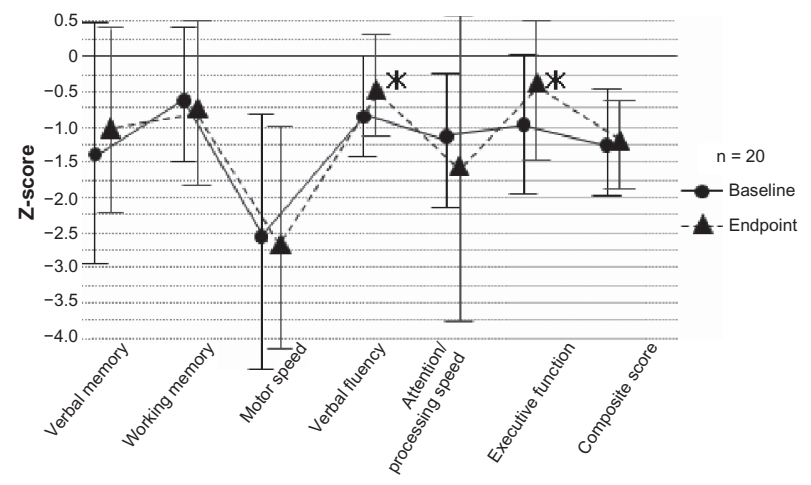

Figure I Changes in z-score of BACS-J subscales at baseline and endpoint. Notes: The data are the mean \pm standard deviation. Z-score was calculated by using the mean raw scores and standard deviation of each assessment in pooled healthy controls $(n=340)$. A composite score was calculated by averaging all $z$-scores of the six subscale measures. Paired $t$-tests were used to compare changes in z-score.

Abbreviation: BACS-J, Brief Assessment of Cognition in Schizophrenia in a Japanese-language version.
However, it demonstrated a 1.62 higher risk of akathisia than risperidone $(P=0.003, \mathrm{NNH}=3)$. No significant differences were found in the rate of other adverse events between blonanserin and other pooled antipsychotics. In addition, no differences were found in discontinuation due to adverse events $(P=0.56)$ or death $(P=0.33)$.

\section{Long-term treatment}

The long-term safety and tolerability of blonanserin were evaluated in three open-label, non-comparative studies in Japan. ${ }^{30-32}$ However, the number of patients who completed the longest-term study ${ }^{32}$ was very small $(n=9)$, and thus, these data are not discussed in this section.

Long-term treatment with blonanserin is generally well tolerated. The overall incidence of adverse drug reactions did not increase during blonanserin therapy for 56 weeks $\left(72.1 \%^{30}\right.$ and $\left.68.5 \%^{31}\right)$. Serious adverse reactions were observed in $9.8 \%{ }^{30}$ and $5.9 \%{ }^{31}$ of patients. However, only two patients reported serious adverse events, including stupor, anxiety, irritability, and akathisia, which were considered to be related to treatment with blonanserin. ${ }^{31}$

The most frequent adverse reactions with blonanserin were EPS, which were observed in $52.5 \%{ }^{30}$ and $35.8 \%{ }^{31}$ of patients. The most commonly (ie, incidence $>10 \%$ ) reported EPS were akathisia $\left(32.8 \%{ }^{30}\right.$ and $\left.17.1 \%{ }^{31}\right)$, tremor $\left(21.3 \%^{30}\right.$ and $\left.15.9 \%^{31}\right)$, and hypokinesia $\left(13.1 \%^{30}\right.$ and $\left.10.9 \%{ }^{31}\right)$. However, significant mean decreases $(P<0.01)$ from baseline were noted in the Drug-Induced Extrapyramidal Symptoms Scale total score and overall severity score after 28 and 52-56 weeks of treatment with blonanserin. ${ }^{30,31}$ Newly occurring tardive dyskinesia was not found during the studies. ${ }^{30,31}$

Other frequently reported adverse drug reactions were hyperprolactinemia $\left(34.4 \%{ }^{30}\right.$ and $\left.20.9 \%{ }^{31}\right)$, insomnia $\left(18.0 \%^{30}\right.$ and $\left.17.4 \%^{31}\right)$, somnolence $\left(16.4 \%^{30}\right.$ and $\left.12.8 \%{ }^{31}\right)$, thirst $\left(14.8 \%{ }^{30}\right)$, constipation $\left(12.8 \% \%^{31}\right)$, and dizziness $\left(11.5 \%{ }^{30}\right)$. Of note, at week 52 or 56 , mean changes from baseline in serum prolactin levels were $-8.4 \mathrm{ng} / \mathrm{mL}^{30}$ and $-5.0 \mathrm{ng} / \mathrm{mL} .{ }^{31}$ Moreover, the incidence of abnormal menstruation was low $\left(6.6 \%^{30}\right.$ and $\left.1.9 \%{ }^{31}\right)$.

Weight gain was reported in $8.2 \%{ }^{30}$ and $5.0 \%{ }^{31}$ of patients. However, no significant changes from baseline in body weight were noted at week 52 or 56 (from 60.5 to $61.5 \mathrm{~kg}^{30}$ and 62.3 to $62.5 \mathrm{~kg}^{31}$ ). Results also showed no significant changes in fasting glucose, cholesterol, or triglycerides..$^{30,31}$ The incidence of QTc interval prolongation was very low; only one of $321(0.3 \%)$ blonanserin recipients experienced this adverse event. ${ }^{31}$ 


\section{The place of blonanserin in therapy and future perspectives}

Although a number of antipsychotic drugs are currently available on the market, certain needs in the treatment of schizophrenia have clearly not yet been met. ${ }^{3}$ Available antipsychotics are considerably effective for positive symptoms of schizophrenia, but they do little to improve negative symptoms and cognitive impairments, which are recognized as core features of schizophrenia and play a greater role in poor functional outcome. ${ }^{1}$

Furthermore, many of the available FGAs can cause acute and chronic EPS, and SGAs can cause considerable weight gain and metabolic abnormalities. ${ }^{3,4}$ Accordingly, an antipsychotic drug that can alleviate negative and cognitive symptoms as well as positive symptoms of schizophrenia and that is metabolically neutral and has a low propensity for EPS is absolutely needed. Several SGAs already meet some of these conditions, but an alternative would be helpful. ${ }^{12,45}$

As described previously, oral blonanserin showed shortand long-term efficacy for treating both positive and negative symptoms of schizophrenia in several randomized and noncomparative studies. Blonanserin was as effective as haloperidol and risperidone for primary endpoints in three 8-week, randomized, double-blind trials, ${ }^{27-29}$ although it appeared to be better than haloperidol in ameliorating negative symptoms. ${ }^{27}$ Moreover, blonanserin improved some types of cognitive function associated with prefrontal cortical function in patients with first-episode and chronic schizophrenia. ${ }^{41,42}$

Blonanserin appears to be generally well tolerated and has minimal effects on weight, metabolic parameters, and QTc interval. It may have tolerability benefits regarding prolactin elevation compared with risperidone. Taken together, these data suggest that blonanserin may be a promising candidate for a first-line antipsychotic for patients with first-episode and chronic schizophrenia.

However, one limitation is that individuals who participated in the Phase III trials may be dissimilar to patients routinely encountered in clinical practice in terms of comorbid psychiatric and somatic conditions. No evidence currently exists to demonstrate that blonanserin may be useful as an alternative to clozapine in treatment-resistant schizophrenia. Additional clinical studies with a broader population of patients with schizophrenia will be useful.

\section{Conclusion}

Blonanserin appears to be effective for a wide range of symptoms in adult patients with first-episode and multiple episodes of schizophrenia. The data provide initial support for a potential cognitive benefit of blonanserin in schizophrenia.
The drug has a low propensity to cause weight gain, metabolic abnormalities, and prolactin elevation. Further large-scale long-term trials comparing blonanserin with other SGAs, especially regarding relapse prevention, QOL, and functional ability of patients, are warranted to establish its efficacy, safety, and effectiveness for the treatment of schizophrenia.

\section{Disclosure}

Dr Tenjin has received speaker's honoraria from Dainippon Sumitomo. Dr Miyamoto is a consultant for Dainippon Sumitomo and has received advisory board honoraria from Chugai Pharmaceutical and speaker's honoraria from Dainippon Sumitomo and Eli Lilly. Dr Miyake has received speaker's honoraria from Dainippon Sumitomo, Eli Lilly, Mitsubishi Tanabe, Otsuka, and Yoshitomi. Drs Tenjin, Miyamoto, and Miyake declare that they have no direct conflict of interest or grant support that is directly related to the content of this article. Dr Yamaguchi has received advisory board and/or speaker's honoraria from Daiichi Sankyo, Eizai, Eli Lilly, Janssen, Otsuka, and Takeda. The other authors have no conflicts of interest to declare.

\section{References}

1. Insel TR. Rethinking schizophrenia. Nature. 2010;468(7321):187-193.

2. Miyamoto S, Duncan GE, Goff DC, Lieberman JA. Therapeutics of Schizophrenia. In: Davis KL, Charney D, Coyle JT, Nemeroff C, editors. Neuropsychopharmacology: The Fifth Generation of Progress. Philadelphia: Lippincott Williams \& Wilkins; 2002:775-807.

3. Miyamoto S, Miyake N, Jarskog LF, Fleischhacker WW, Lieberman JA. Pharmacological treatment of schizophrenia: a critical review of the pharmacology and clinical effects of current and future therapeutic agents. Mol Psychiatry. 2012;17(12):1206-1227.

4. Miyamoto S, Fleischhacker WW, Lieberman JA. Pharmacologic treatment of schizophrenia. In: Lieberman JA, Murray RM, editors. Comprehensive Care of Schizophrenia (Second Edition): A Textbook of Clinical Management. New York: Oxford University Press; 2012:77-138.

5. Jones PB, Barnes TR, Davies L, et al. Randomized controlled trial of the effect on Quality of Life of second- vs first-generation antipsychotic drugs in schizophrenia: Cost Utility of the Latest Antipsychotic Drugs in Schizophrenia Study (CUtLASS 1). Arch Gen Psychiatry. 2006;63(10): 1079-1087.

6. Kahn RS, Fleischhacker WW, Boter H, et al. Effectiveness of antipsychotic drugs in first-episode schizophrenia and schizophreniform disorder: an open randomised clinical trial. Lancet. 2008;371(9618):1085-1097.

7. Leucht S, Corves C, Arbter D, Engel RR, Li C, Davis JM. Secondgeneration versus first-generation antipsychotic drugs for schizophrenia: a meta-analysis. Lancet. 2009;373(9657):31-41.

8. Lieberman JA, Stroup TS, McEvoy JP, et al. Effectiveness of antipsychotic drugs in patients with chronic schizophrenia. $N$ Engl J Med. 2005;353(12):1209-1223.

9. Buchanan RW, Kreyenbuhl J, Kelly DL, et al. The 2009 schizophrenia PORT psychopharmacological treatment recommendations and summary statements. Schizophr Bull. 2010;36(1):71-93.

10. Hasan A, Falkai P, Wobrock T, et al. World Federation of Societies of Biological Psychiatry (WFSBP) Guidelines for Biological Treatment of Schizophrenia, part 1: update 2012 on the acute treatment of schizophrenia and the management of treatment resistance. World J Biol Psychiatry. 2012;13(5):318-378. 
11. Lehman AF, Lieberman JA, Dixon LB, et al. Practice Guideline for the Treatment of Patients with Schizophrenia, 2nd ed. Am J Psychiatry. 2004;161(Suppl 2):1-56.

12. Miyake N, Miyamoto S, Jarskog LF. New serotonin/dopamine antagonists for the treatment of schizophrenia: are we making real progress? Clin Schizophr Relat Psychoses. 2012;6(3):122-133.

13. Kishi T, Matsuda Y, Nakamura H, Iwata N. Blonanserin for schizophrenia: Systematic review and meta-analysis of double-blind, randomized, controlled trials. J Psychiatr Res. 2013;47(2):149-154.

14. Une T, Kurumiya S. Pharmacological profile of blonanserin. Jpn J Clin Psychopharmacol. 2007;10(7):1263-1272.

15. Murasaki M. Preclinical and clinical features of blonanserin. Jpn J Clin Psychopharmacol. 2008;11(5):855-868.

16. Deeks ED, Keating GM. Blonanserin: a review of its use in the management of schizophrenia. CNS Drugs. 2010;24(1):65-84.

17. Oka M, Noda Y, Ochi Y, et al. Pharmacological profile of AD-5423, a novel antipsychotic with both potent dopamine-D2 and serotonin-S2 antagonist properties. J Pharmacol Exp Ther. 1993;264(1):158-165.

18. Murasaki M, Nishikawa H, Ishibashi T. Dopamine-serotonin antagonist: Receptor binding profile of a novel antipsychotic blonanserin. Jpn $J$ Clin Psychopharmacol. 2008;11(5):845-854.

19. Ohoyama K, Yamamura S, Hamaguchi T, et al. Effect of novel atypical antipsychotic, blonanserin, on extracellular neurotransmitter level in rat prefrontal cortex. Eur J Pharmacol. 2011;653(1-3):47-57.

20. Lonasen ${ }^{\circledR}$ (blonanserin) [interview form]. Osaka, Japan: Dainippon Sumitomo Pharma Co, Ltd; 2012.

21. Suzuki H, Gen K. The relationship between the daily dose, the plasma concentration of blonanserin, and its plasma anti-dopamine D2 and anti-serotonin 5-HT2A activity. Hum Psychopharmacol. 2010;25(4):342-346.

22. Inoue $\mathrm{T}$, Osada $\mathrm{K}$, Tagawa $\mathrm{M}$, et al. Blonanserin, a novel atypical antipsychotic agent not actively transported as substrate by P-glycoprotein. Prog Neuropsychopharmacol Biol Psychiatry. 2012;39(1):156-162.

23. Arakawa R, Okumura M, Ito $\mathrm{H}$, et al. Positron emission tomography measurement of dopamine $\mathrm{D}(2)$ receptor occupancy in the pituitary and cerebral cortex: relation to antipsychotic-induced hyperprolactinemia. J Clin Psychiatry. 2010;71(9):1131-1137.

24. Tateno A. PET evaluation for dopamine D2 receptor occupancy of blonanserin in schizophrenia patients. Jpn J Clin Psychopharmacol. 2011;14(2):334-341.

25. Saruwatari J, Yasui-Furukori N, Inoue Y, Kaneko S. Effect of dose timing in relation to food intake on systemic exposure to blonanserin. Eur J Clin Pharmacol. 2010;66(9):899-902.

26. Garcia E, Robert M, Peris F, Nakamura H, Sato N, Terazawa Y. The efficacy and safety of blonanserin compared with haloperidol in acutephase schizophrenia: a randomized, double-blind, placebo-controlled, multicentre study. CNS Drugs. 2009;23(7):615-625.

27. Murasaki M. Clinical evaluation of blonanserin for schizophrenia: a randomized controlled study comparing blonanserin with haloperidol. Jpn J Clin Psychopharmacol. 2007;10(11):2059-2079.

28. Miura S. Clinical evaluation of blonanserin for schizophrenia: a randomized controlled study comparing blonanserin with risperidone. Jpn J Clin Psychopharmacol. 2008;11(2):297-314.

29. Yang J, Bahk WM, Cho HS, et al. Efficacy and tolerability of Blonanserin in the patients with schizophrenia: a randomized, double-blind, risperidone-compared trial. Clin Neuropharmacol. 2010;33(4):169-175.
30. Murasaki M. Long-term clinical study of blonanserin for schizophrenia: a multicenter open study to determine safety and effectiveness in schizophrenic patients (Kanagawa Region Clinical Psychopharmacology Study Group). Jpn J Clin Psychopharmacol. 2007;10(12):2241-2257.

31. Kinoshita T. Long-term clinical study of blonanserin for schizophrenia: a multicenter open study to determine safety and effectiveness in schizophrenic patients (Japan-wide study). Jpn J Clin Psychopharmacol. 2008;11(1):135-153.

32. Osada K, Miyamoto S, Maruta S, Miyake N, Nakano M, Yamaguchi N. Long-term clinical study of blonanserin for schizophrenia: a multicenter open study to assess the safety and efficacy in patients with schizophrenia (Continuation of two long-term studies by request from patients). Jpn J Clin Psychopharmacol. 2009;12(11):2337-2351.

33. Green MF, Kern RS, Braff DL, Mintz J. Neurocognitive deficits and functional outcome in schizophrenia: are we measuring the "right stuff"? Schizophr Bull. 2000;26(1):119-136.

34. Gold JM, Harvey PD. Cognitive deficits in schizophrenia. Psychiatr Clin North Am. 1993;16(2):295-312.

35. Mesholam-Gately RI, Giuliano AJ, Goff KP, Faraone SV, Seidman LJ. Neurocognition in first-episode schizophrenia: a meta-analytic review. Neuropsychology. 2009;23(3):315-336.

36. Bozikas VP, Andreou C. Longitudinal studies of cognition in first episode psychosis: a systematic review of the literature. Aust N Z J Psychiatry. 2011;45(2):93-108.

37. Bilder RM, Goldman RS, Robinson D, et al. Neuropsychology of firstepisode schizophrenia: initial characterization and clinical correlates. Am J Psychiatry. 2000;157(4):549-559.

38. Saykin AJ, Shtasel DL, Gur RE, et al. Neuropsychological deficits in neuroleptic naive patients with first-episode schizophrenia. Arch Gen Psychiatry. 1994;51(2):124-131.

39. Wolwer W, Brinkmeyer J, Riesbeck M, et al. Neuropsychological impairments predict the clinical course in schizophrenia. Eur Arch Psychiatry Clin Neurosci. 2008;258 Suppl 5:28-34.

40. Matsui M, Sumiyoshi T, Arai H, Higuchi Y, Kurachi M. Cognitive functioning related to quality of life in schizophrenia. Prog Neuropsychopharmacol Biol Psychiatry. 2008;32(1):280-287.

41. Miyake N, Miyamoto S, Takeuchi A, et al. Effect of new-generation antipsychotic blonanserin on cognitive impairment in schizophrenia: A randomized double-blind comparison with risperidone. Jpn J Clin Psychopharmacol. 2008;11(2):315-326.

42. Tenjin T, Miyamoto S, Miyake N, et al. Effect of blonanserin on cognitive function in antipsychotic-naive first-episode schizophrenia. Hum Psychopharmacol. 2012;27(1):90-100.

43. Kaneda Y, Sumiyoshi T, Keefe R, Ishimoto Y, Numata S, Ohmori T. Brief assessment of cognition in schizophrenia: validation of the Japanese version. Psychiatry Clin Neurosci. 2007;61(6):602-609.

44. Kaneda Y, Imakura A, Fujii A, Ohmori T. Schizophrenia Quality of Life Scale: validation of the Japanese version. Psychiatry Res. 2002; 113(1-2):107-113.

45. Miyamoto S, Merrill DB, Lieberman JA, Fleischhacker WW, Marder SR. Antipsychotic Drugs. In: Tasman A, Kay J, Lieberman JA, First MB, Maj M, editors. Psychiatry, 3rd ed. Chichester: John Wiley \& Sons; 2008:2161-2201.
Neuropsychiatric Disease and Treatment

\section{Publish your work in this journal}

Neuropsychiatric Disease and Treatment is an international, peerreviewed journal of clinical therapeutics and pharmacology focusing on concise rapid reporting of clinical or pre-clinical studies on a range of neuropsychiatric and neurological disorders. This journal is indexed on PubMed Central, the 'PsycINFO' database and CAS.

\section{Dovepress}

The manuscript management system is completely online and includes a very quick and fair peer-review system, which is all easy to use. Visit http://www.dovepress.com/testimonials.php to read real quotes from published authors. 